\title{
Late-night noise hazards and the Tokyo Metropolitan Government's countermeasures in the 1960s
}

\author{
Junichi Hasegawa ${ }^{* \dagger}$ \\ Faculty of Economics, Keio University, 2-15-45 Mita, Minato-ku, Tokyo 108-8345, Japan \\ ${ }^{*}$ Corresponding author. Email: hasegawa@econ.keio.ac.jp
}

\begin{abstract}
In 1960s Tokyo, late-night noise became a source of annoyance for urban-dwellers in residential areas. The problem was primarily due to young people who congregated around small food establishments eating and drinking. The situation led to the Tokyo Metropolitan Government to attempt to remove such small businesses through the 1969 Environmental Pollution Prevention Ordinance. However, the section of the ordinance dealing with late-night noise hazards was diluted by the political parties, who supported the interests of such businesses, hence failing to satisfy local residents who were victims of the problem.
\end{abstract}

\section{Introduction}

In the late 1960s, late-night noise hazard problems became a significant issue in Tokyo, beginning with the encroachment of small food establishments serving youths alcoholic drinks and light meals in residential areas. The Tokyo Metropolitan Government (TMG) attempted to resolve it through the Environmental Pollution Prevention Ordinance (the Pollution Prevention Ordinance) of 1969, renowned for its unprecedented emissions standards regarding air and water pollution. ${ }^{1}$ Nevertheless, the developments and consequences of the regulations against latenight noise hazards remain unstudied. This article examines how the TMG tackled the late-night noise hazards in which the tranquillity of residents and the freedom of business of small traders had to be weighed, and whether it provided effective regulations against them. It reveals that the TMG, which governed the fast-growing and changing city, diluted its measures to prioritize the interests of residents because of pressure from the political parties on the Tokyo Metropolitan Assembly (TMA) to defend the interests of small businesses. This raises important questions for the

\footnotetext{
${ }^{\dagger}$ I would like to thank Professor Simon Gunn and the two anonymous referees for their comments and suggestions, which have done much to improve this article. I am also grateful to Mr Keegan Cothern for his valuable comments and suggestions.

${ }^{1}$ S. Avenell, Transnational Japan in the Global Environmental Movement (Honolulu, 2017), 39.

(C) The Author(s), 2021. Published by Cambridge University Press. This is an Open Access article, distributed under the terms of the Creative Commons Attribution licence (http://creativecommons.org/licenses/by/4.0/), which permits unrestricted re-use, distribution and reproduction, provided the original article is properly cited.
} 
understanding of Japanese politics and the urban history of Japan during this period. Tokyo's population, 3.488 million in 1945 immediately after World War II, expanded to 9.683 million in 1960 and then to 11.408 million in $1970 .^{2}$ The preparation for the Olympics brought the modern Olympic installations and transport systems such as the bullet train, the monorail connecting the airport to the city centre and a network of elevated motorways. ${ }^{3}$ At the same time, this noise issue - faced by the TMG occurred in several of Tokyo's sedate residential areas.

Noise attracted attention as an environmental problem following the enactment of the Basic Law for Environmental Pollution Control (Basic Law) in 1967, the first significant state legislative measure against pollution. It stipulated that to develop integrated measures for the protection of the living environment of the population, the measures of pollution control should cover air, water and noise pollution. ${ }^{4}$ Categorized as an environmental problem, noise was considered an urban problem for urban-dwellers in large cities. As the Prime Minister's Office's 1969 White Paper noted, noise complaints lodged with the authorities accounted for 50-60 per cent of the total number of pollution complaints in five of the six major cities including Tokyo. ${ }^{5}$ Furthermore, regulating noise was increasingly difficult as noise had distinctive features among environmental problems. Generally, the issue of water or air pollution was presented as a conflict between citizens as victims and large industrial firms (and the state) as perpetrators, typically involving the entire population of a city or river basin. Of particular public interest were the so-called four major pollution-related diseases in the provincial industrial areas caused by water poisoning or air pollution due to industrial emissions. ${ }^{6}$ Victims of these diseases won court battles to receive compensation from the responsible companies. There were also residents' movements formed to exert political pressure, which succeeded in preventing large-scale industrial development in the provinces. ${ }^{7}$

Against this, noise hazards were predominantly recognized as a private nuisance involving conflicting civic interests in a neighbourhood, rendering both their regulation and resolution of complaints difficult. ${ }^{8}$ It was not a case of the citizens versus the polluting large company, but, rather, the citizens were the perpetrators and the victims simultaneously. In this case of late-night noise hazards, it was a case of the economic concern of small businesses versus the environmental concern of the residents. Moreover, as experts pointed out, due to the subjectivity of sound perception, quantifying the levels of noise for specific disturbances was objectively difficult. ${ }^{9}$ Resolving noise issues was a difficult task for the TMG - when it attempted to

\footnotetext{
${ }^{2}$ Tokyo Metropolitan Government (ed.), Tokyo Statistical Yearbook (Tokyo, 1971), 14-15.

${ }^{3}$ E. Seidensticker, Tokyo Rising (Rutland, VT, and Tokyo, 1991), 228-81.

${ }^{4}$ Kōseishō Kankyōeiseikyokukōgaibu (ed.), Sōonkiseihō no Kaisetsu (Tokyo, 1969), 4.

${ }^{5}$ Sōrifu (ed.), Kōgaihakusho (Shōwa 44nenban) (Tokyo, 1969), 96-7.

${ }^{6}$ Avenell, Transnational Japan, 24-51. Also see, for the Minamata disease, which was the first condition recognized widely among the four major pollution-related diseases, T. George, Minamata. Pollution and the Struggle for Democracy in Postwar Japan (Cambridge and London, 2001).

${ }^{7}$ K. Hasegawa, Constructing Civil Society in Japan (Melbourne, 2004) (translation of his Kankyōundō to atarashii Kōkyōken (Tokyo, 2003)), 37-47; and Jeffrey Broadbent, Environmental Politics in Japan: Networks of Power and Protest (Cambridge and New York, 1998).

${ }^{8}$ 'Zadankai seikatsubōgai (kōgai) to sono kyūsai', Jurisuto, 309 (1964), 15-19.

${ }^{9}$ Kōgaikenkyūkai, 'Nihon no kōgaihō (jō)', Jurisuto, 308 (1964), 32-3.
} 
impose a total ban on late-night businesses in residential areas (to preserve tranquillity for the sake of urban-dwellers), conflicting civic interests worked to create a compromise that was unattractive to all parties.

Examining this issue contributes to the understanding of Japanese politics and of Japanese urban history during this period through reconsidering the TMG's related achievements. Moreover, such examination is important given the international dimension of urban noise, as the 1960s saw an increased awareness of 'noise pollution' worldwide. ${ }^{10}$

Japanese politics during this period were typified by the rise of progressive local governments, led by progressive prefectural governors and mayors, which applied drastic measures, particularly in welfare and environmental issues. They were supported by the two left-wing political parties, the Japan Socialist Party (JSP) and the Japanese Communist Party (JCP). Ryokichi Minobe, a Marxist scholar who held the position of the Tokyo metropolitan governor for 12 years from 1967, was a representative example of such progressive leaders. He ran as an independent supported by a citizens' voluntary organization, along with the JSP and the JCP. The election of Minobe in 1967 is considered to mark the epoch of the progressive local governments in full swing. ${ }^{11}$

The achievement of the progressive local governments was the emphasis on citizen participation and local autonomy. Particularly important were the efforts of local governments to respond to the needs of the population and to force a change in national policy by the conservative Liberal Democratic Party (LDP) national administration, which had been in power since 1955, through such measures as ordinances and agreements. ${ }^{12}$ These efforts were seen as enhancing the estimation of the progressive local governments, potentially threatening the LDP national government. ${ }^{13}$ The National Association of Progressive Mayors had mayors from 21 cities in $1966 .{ }^{14}$ By 1972, this number had grown to 124 , representing approximately 20 per cent of all 639 cities across the nation. ${ }^{15}$ Minobe focused on social welfare and anti-pollution policies. He financed unlicensed nurseries, despite opposition from the Welfare Ministry and the LDP, and established a child allowance system and free medical care for underprivileged elderly citizens well in advance of state provisions, as well as the 1969 Pollution Prevention Ordinance. ${ }^{16}$

Nevertheless, by the late 1970s, the progressive local governments found difficulties in pursuing their policies and were weakening. Various factors have been cited as contributing to this decline. The political parties' support base for the progressive local governments weakened as the relationship between the JSP and the JCP deteriorated in the early 1970s. The progressive leaders also had difficulty in dealing

\footnotetext{
${ }^{10}$ M. Schaffer, The Book of Noise (Vancouver, 1970).

${ }^{11}$ T. Kunugi, 'Kakushinshisei hattenzenshi (1)', Gyōseishakaironsyū, 20 (2008), 78.

${ }^{12}$ S. Takayose, Chihōseiji no Hoshu to Kakushin (Tokyo, 1981), 60-7.

${ }^{13}$ G.D. Allinson, 'Opposition in the suburbs', S.C. Flanagan, 'National and local voting trends', and K. Steiner, 'Progressive local administration', in K. Steiner, E. Krauss and S. Flanagan (eds.), Political Opposition and Local Politics in Japan (Princeton, 1980), 95-130, 131-84 and 317-52.

${ }^{14}$ Yomiuri Shimbun (Yomiuri), 26 Oct. 1966.

${ }^{15}$ Asahi Shimbun (Asahi), 11 Sep. 1972. For the detailed analyses of the growth of progressive mayors, see T. Kunugi, 'Kakushinshisei hattenzenshi (3)', Gyōseishakaironsyū, 21 (2008), esp. 1-45.

${ }^{16} \mathrm{H}$. Tsukada, Tokyoto no Shōzō (Tokyo, 2002), 155-60; M. Minagawa, Tokyo Shisei (Tokyo, 2007), 274-6.
} 
with a council or assembly dominated by conservative forces. The emphasis on the right to local self-government and welfare policies, which had been spearheaded by the progressive leaders, was followed by the conservatives and became established in both conservative and progressive circles. ${ }^{17}$

Nonetheless, these factors did not apply to the Minobe Metropolitan Government in 1969, when the Pollution Prevention Ordinance was enacted. The reputation of the Minobe government was sound and Minobe scored a great victory in the 1971 gubernatorial election with the solid support of the JSP and JCP. In the TMA, at the time of the enactment of the Pollution Prevention Ordinance, the number of seats held by the largest JSP and the JCP, though not reaching a majority, reached 54 out of 120, exceeding the LDP's 38 . The Minobe TMG's intention to impose a total ban on late-night businesses in residential areas was in the interests of urban-dwellers. This article reveals that even at the height of its power as a progressive local government in the 1960s, the political parties on the TMA, including the JSP and the JCP, supporters of Minobe stood in the way of the TMG promoting measures for the issue.

Within Japanese urban history, the 1960s is regarded as an important period that saw advancements in enacting related legislation and discussing policy. A series of state laws on environmental pollution - as well as the City Planning Law - were enacted, and urban policy, with its emphasis on the supply of housing in large cities, became an important issue in national elections. Citizen activism and protest against environmental problems and the increasing political opposition represented by the progressive local governments have been considered crucial in pressurizing the LDP government to prompt action. ${ }^{18}$

However, the urban policy measures for housing for urban-dwellers were not as substantive as the policy changes regarding environmental pollution. The LDP government had responded to the protests against pollution by establishing the Basic Law in 1967; however, criticism was rife that its clause, emphasizing that environmental protection should be in balance with sound economic development, did not represent a philosophy that placed greater emphasis on environmental protection. Accordingly, the 1970 Diet Session saw 14 pieces of legislation passed on environmental pollution, including the revised Basic Law, which had removed the muchcriticized clause. $^{19}$

During this same period, the LDP government tackled urban problems in large cities, such as cramped housing conditions in built-up areas, urban sprawl in outskirts and the skyrocketing price of land everywhere, by enacting the City Planning Law in 1968. The emphasis was on increasing the allocation of land for housing to increase the housing supply. Farmers in urban areas expected that their agricultural land would increase in value since the tax rate on agricultural land was lower than the rate on land intended for construction. The local tax law was to be revised to

\footnotetext{
${ }^{17}$ Takayose, Chihōseiji no Hoshu to Kakushin, 78-80; H. Shindo, 'Kakushinjichitai', in O. Watanabe (ed.), Kōdoseichō to Kigyōshakai (Tokyo, 2004), 246-9; and I. Okada, Kakushinjichitai (Tokyo, 2016), $180-4$.

${ }^{18}$ Y. Ishida, Nihon Kingendai Toshikeikaku no Tenkai 1868-2003 (Tokyo, 2004), 249-54; and A. Sorensen, The Making of Urban Japan: Cities and Planning from Edo to the Twenty-First Century (London, 2002), 200-13.

${ }^{19}$ S. Tsuru, The Political Economy of the Environment: The Case of Japan (London, 1999), 58-69.
} 
equalize both rates so that farmers living in the urbanization promotion areas (prescribed in the City Planning Law as areas to be developed) would be incentivized to offer their land for development. ${ }^{20}$

However, the revision of the tax on agricultural land continued to be postponed, further encouraging farmers to retain their agricultural land in expectation of a rise in land prices. The political parties on the National Diet, including the opposition JSP and JCP, wished to exempt farmers from the proposed tax reforms. The farmers' association could exert substantial influence over political parties by strategically distributing organized votes to them, whereas it was considered difficult to win votes from urban-dwellers, who had a substantive cohort regarded as floating voters. Considering that the public housing by local authorities was confined to those on low income, voters in large cities expressed their dissatisfaction in the newspapers at the lack of effective urban policy measures to ensure ample supply of decent housing during national elections. ${ }^{21}$

Against this backdrop, the TMG attempted to impose a total ban on late-night businesses for urban-dwellers, but facing opposition from the political parties on the TMA, it compromised by limiting the scope of a total ban. The process casts doubts on the ability of the TMG to address issues that involved conflicting civic interests, and, by extension, on the role of progressive local government, which was thought to have advanced environmental and urban policies during this period in Japanese urban history.

As for the international dimension of urban noise, recent studies suggest that in the nineteenth and early twentieth centuries - the reaction against urban noise in the western world focused on obtaining quietness as a private commodity. ${ }^{22}$ Conversely, regulating neighbourhood domestic noise was considered difficult as the twentieth century progressed because the right for citizens to make private noise for leisure was acknowledged, whereas the sound perception was considered subjective. ${ }^{23}$ Nonetheless, the acute awareness in the 1960s saw an increase in the number of anti-noise legislative measures worldwide. These measures reveal specific cultural attitudes toward noise phobias. For instance, many European cities restricted disturbing activities during daily break periods or activities disturbing tranquillity during summer nights, such as outdoor bowling. Moreover, a specific sound was recognized as a particular cause of noise complaints, such as the restaurant sound of pounding veal for schnitzels in Essen, Germany, and the sound of mah jong in Hong Kong and the Chinese districts of Vancouver and San Francisco. ${ }^{24}$ In Japan, where rice is the staple food, the earliest court cases on noise and vibration issues up to the end of the 1960s involved the use of rice milling machines and irrigation pumps as noise sources in the 1910s. However,

\footnotetext{
${ }^{20}$ J. Hasegawa, 'Drafting of the 1968 Japanese City Planning Law', Planning Perspectives, 29 (2014), 231-8.

${ }^{21} \mathrm{~K}$. Calder, Crisis and Compensation (Princeton, 1988), 376-410; and J. Hasegawa 'The political motivations for the reform of urban policy during the rapid economic growth period in Japan', Urban History, 48 (2021), 364-79.

${ }^{22}$ J. Picker, Victorian Soundscapes (Oxford, 2003), 41-81; and E. Thompson, The Soundscape of Modernity (Cambridge, MA, 2004), 169-228.

${ }^{23}$ K. Bijsterveld, Mechanical Sound: Technology, Culture, and Public Problems of Noise in the Twentieth Century (Cambridge, MA, 2008), 159-91.

${ }^{24}$ M. Schaffer, The Soundscape (Rochester, VT, 1994 edn), 191-200.
} 
the majority of the court cases concerned noise from small-sized factories in areas where there was a mix of residential and industrial buildings, as well as noise from building work. $^{25}$ This article examines how a regulatory framework was developed to address the problem of noise from commercial activities for entertainment as a source of noise, which had previously been rare in Japan.

This article is based on various sources, such as the major national newspapers (Asahi Shimbun (Asahi), Mainichi Shimbun (Mainichi) and Yomiuri Shimbun (Yomiuri)); the minutes of the National Diet (accessed on the National Diet Library's website: https://kokkai.ndl.go.jp) and the TMA and its committees (archived at the Tokyo Metropolitan Assembly Library); and related materials from the Tokyo Metropolitan Archives. ${ }^{26}$

\section{Late-night noise hazards}

The noise hazard problem started in Harajuku, which is recognized as an important hub of Japan's youth culture today. In the mid-1960s, as Yomiuri described, it was 'an exclusive residential district'. ${ }^{27}$ Its main axis, Omotesandō, leads to the main entrance of the Meiji Shrine - built in 1920 to enshrine the Meiji emperor (d. 1912) and the dowager empress (d. 1914). Only special days, such as the Shrine's Festival Day, the autumn Children's Day and New Year's Day, brought numerous visitors to an otherwise quiet Harajuku. ${ }^{28}$

The 1964 Tokyo Olympics influenced the evolution of Harajuku into a centre for youth culture. The town provided the Olympic Village (now the Yoyogi Park), Yoyogi National Stadium and the International Broadcasting Centre (now the NHK, namely, Japan Broadcasting Corporation, Broadcasting Centre) in a $920,000 \mathrm{~m}^{2}$ area to the south of the Shrine. This was formerly a secluded housing area for US Air Force families, named Washington Heights. ${ }^{29}$ Several exotic latenight bars and restaurants opened along Omotesandō, originally catering to Olympic participants. Harajuku soon attracted 'curious and mildly rebellious' Japanese youths called Harajuku-zoku (the Harajuku tribe). They gathered in these late-night establishments located on the lower floors below newly built luxury flats along Omotesandō or sped along it in their sports cars late at night. ${ }^{30}$ They were also fashion-conscious, attracting trendy boutiques along Omotesandō. However, it was not until the late 1970s that Harajuku gained a reputation as one of the hubs of Japan's youth culture. ${ }^{31}$ This was partly encouraged by the opening and extension of the Chiyoda underground line, which brought large numbers of youths from the surrounding prefectures to Harajuku on weekends. Although the Olympics brought new installations to Harajuku, the town in the 1960s remained a

\footnotetext{
${ }^{25}$ A. Noda, 'Sōon shindō hanrei niokeru hōtekironten no suii', Jurisuto, 390 (1968), 36-43.

${ }^{26}$ The newspapers consulted were the three largest national newspapers in Japan with the circulation numbers for 1970 ranging from 4,628,733 to 5,724,113. Nihonshimbunkyōkai (ed.), Nihonshimbunnenkan Shōwa 45nenban (Tokyo, 1970), 74, 103 and 112.

${ }^{27}$ Yomiuri, evening edition, 16 Dec. 1965, 7.

${ }^{28}$ A. Kato, Harajuku Monogatari (Tokyo, 1986), 95.

${ }^{29}$ S. Akio, Washington Heights (Tokyo, 2009).

${ }^{30}$ Seidensticker, Tokyo Rising, 240.

${ }^{31}$ K. Mabuchi, 'Zoku' tachi no Sengoshi (Tokyo, 1989), 243-9.
} 
calm residential district - apart from Omotesandō. In the 1964 fiscal year, the number of passengers boarding Japan National Railway Corporation trains at Harajuku station was 7.395 million, the smallest number of passengers per year at any of the stations on the Yamanote Loop Line. The corresponding figure for the station with the largest number of passengers was 143.524 million for Tokyo. ${ }^{32}$ In the 1969 fiscal year, the number of passengers at Harajuku was 8.859 million, the smallest number on the Yamanote Loop Line. The corresponding figure for the station with the largest number of passengers was 170.981 million for Shinjuku, an increase of 37.785 million from $1964 .{ }^{33}$ Against this backdrop, Harajuku-zoku youths created an immediate social problem of noise hazards, which subsequently spread to other parts of Tokyo (Figure 1).

Initially, noise hazards referred to noise caused by the Harajuku-zoku youths who sped their cars along Omotesandō. Previous studies of the youth tribes of Japan underscored the most distinctive feature of this first generation of Harajuku-zoku in their late teens and early twenties, who comprised sons of wealthier families. For these young men, vehicle ownership was a must, and fast cars were symbolic of the forthcoming advent of mass-motorization. ${ }^{34}$ However, the nature of the nuisance quickly extended beyond speeding sports cars.

The focus shifted to noise caused by youths congregating around small food establishments, called snack bars, which served their mainly young clientele inexpensive alcoholic drinks and light meals. These establishments spread into the quieter parts of Harajuku and the adjacent district of Aoyama. ${ }^{35}$ Many of the clientele were now young adults in their twenties and thirties, including office workers, writers and television personalities. ${ }^{36}$

The local inhabitants were understandably concerned about the Harajuku-zoku's potentially adverse influences on the local children. ${ }^{37}$ They established the 'Association to Protect the Living Environment' in the autumn of 1966, aiming to expel the Harajuku-zoku. The association's original membership contained approximately 70 people, mainly housewives and retailers. ${ }^{38}$

The late-night noise problem was simultaneously spreading to the outer wards of Tokyo such as Toshima, Nakano, Setagaya, Meguro and Oota. A newspaper article in late September 1967 advised 'strict control as soon as possible or all Tokyo will be occupied' by late-night bars and restaurants. The headline noted that such establishments were 'surviving resiliently' (Figure 2). ${ }^{39}$

The Harajuku-zoku attracted much political attention. The TMA's Police Affairs and Fire Committee discussed the matter on 27 June 1967. Den Harada, director of

\footnotetext{
${ }^{32}$ Tokyo Metropolitan Government (ed.), Tokyo Statistical Yearbook (Tokyo, 1965), 190 and 192.

${ }^{33}$ Tokyo Metropolitan Government (ed.), Tokyo Statistical Yearbook (Tokyo, 1971), 178-9.

${ }^{34}$ Mabuchi, 'Zoku' tachi no Sengoshi, 138-45 and 153-60; K. Namba, Zoku no Keifugaku (Tokyo, 2007), 145-6 and 195; and K. Ichikawa, "Machizoku” wo saikenshō suru', Bungeikenkyū, 122 (2014), 204-5. For the evolution of motorization in Japan in comparison with Britain, see S. Gunn and S. Townsend, Automobility and the City in Twentieth-Century Japan and Britain (London and New York, 2019).

${ }^{35}$ Yomiuri, evening edition, 10 Mar. 1967, 3.

${ }^{36}$ Asahi, 25 Mar. 1967, 15; Yomiuri, evening edition, 25 Mar. 1967, 9; and Mainichi, 2 Jul. 1967, 15.

${ }^{37}$ Asahi, 25 Jul. 1966, 16.

${ }^{38}$ Asahi, 6 Nov. 1966, 15; Asahi, 9 Nov. 1966, 16; and Asahi, 11 Nov. 1966, 14.

${ }^{39}$ Yomiuri, 24 Sep. 1967, 13.
} 


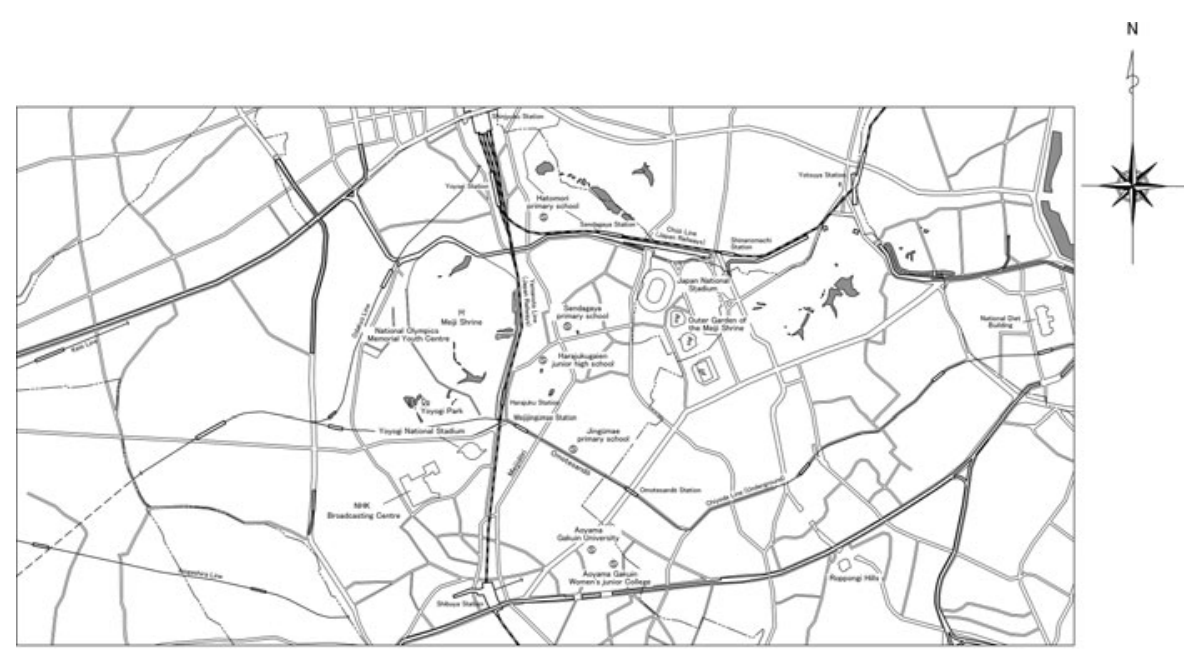

Figure 1. Map of the current Harajuku and surroundings. Before the end of February 1965, Harajuku was the official denomination of the area to the north of Omotesandō.

the Crime Prevention Bureau of the Metropolitan Police, indicated that most of the bars and restaurants were now well-lit and more soundproof. He emphasized the police department's intention to respond through existing legislative measures, such as the Entertainment Businesses Law. Opposing this, Mamoru Kurumada of the JSP criticized Harada's remarks and demanded more punitive laws. Ryoichi Yamazaki of the JCP also criticized the 'lack of positive effort to protect the inhabitants' position'. Zenjiro Sano of the LDP asserted the need for tighter control. Against these, Harada maintained that controlling youths required due consideration of their nurturance and protection, so the authorities should 'refrain from cherishing vaulting ambition to resolve the problems at a single stroke by taking a severe line. ${ }^{40}$

The following day, the House of Representatives Committee on Education (HRCE) focused on the youth problems in Harajuku and Aoyama, particularly the administration of snack bars, which were favoured gathering spots. Taro Yamada of the centrist Kōmeitō Party pressed Giichi Imatake, director of the Security Service of the National Police Agency, to state whether it would be possible to close down such businesses, which as he put it were 'hotbeds of all evils'. Imatake replied that although he had considered new legislative measures that might become necessary, they would continue to deal with the situation through the existing laws because there were various issues to be considered, 'notably the freedom of business. ${ }^{41}$

\footnotetext{
${ }^{40}$ Stenographic Records of the TMA's Police Affairs and Fire Committee, 27 Jun. 1967, 3-13 (quotations 9 and 12).

${ }^{41}$ Minutes of the HRCE, 28 Jun. 1967, 23-6 (quotations 25 and 26).
} 

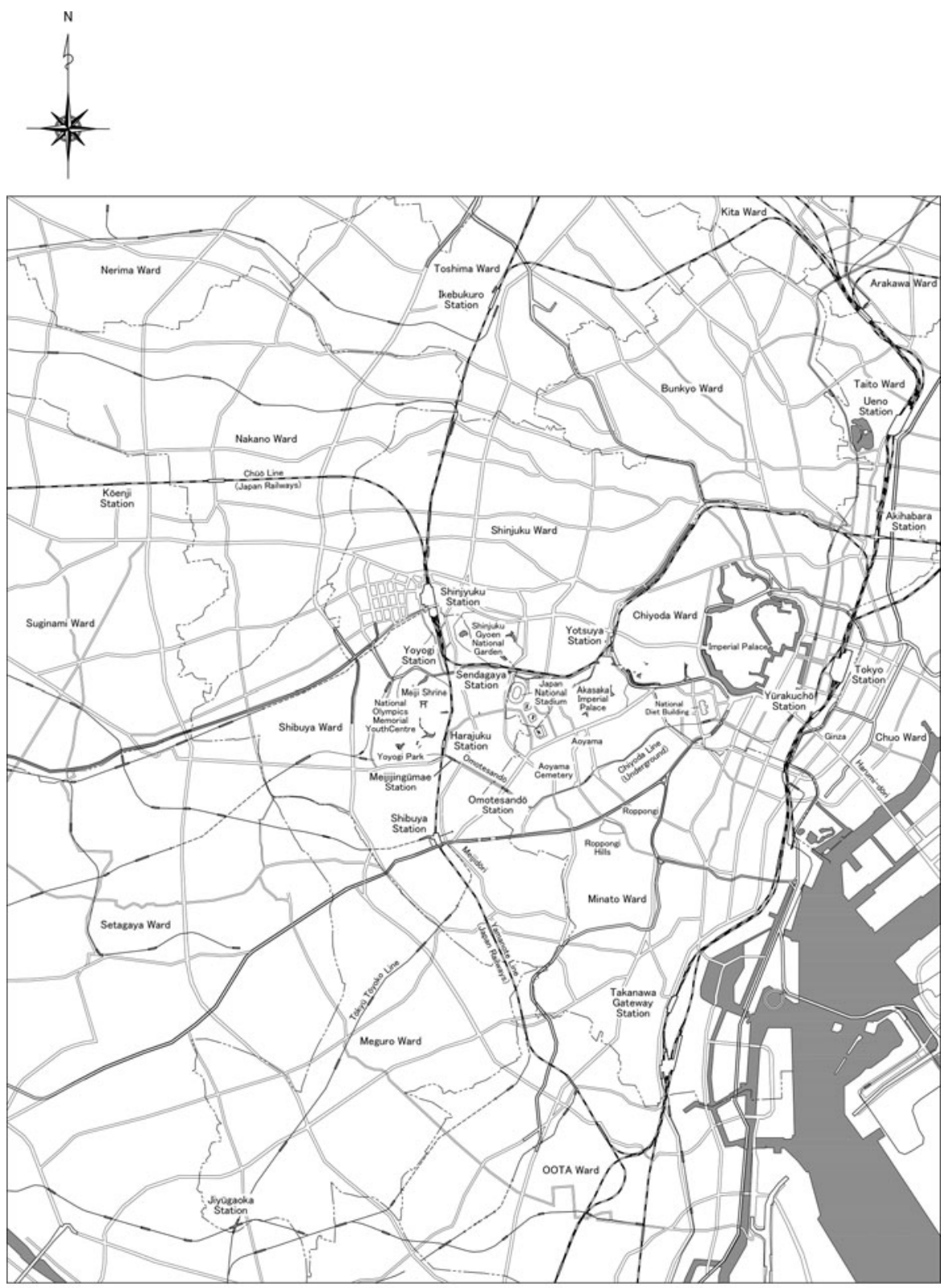

ward boundaries $2 \mathrm{~km}$

Figure 2. Locations of relevant places in Tokyo.

Meanwhile, Asahi reported the feelings of two representatives of the local residents' association, who had attended the HRCE meeting on 28 June 1967. They described the remarks and actions of officials from the concerned departments 
as 'perfunctory and irresponsible', adding that they would advise their association meeting on 1 July not to depend on the authorities. ${ }^{42}$ That meeting later drew approximately 150 inhabitants and two politicians whose constituencies included the Harajuku area: Kosaku Wada, member of the House of Representatives (centrist Democratic Socialist Party), and Shigeru Kitada, member of the TMA (JSP). Morio Takimoto, a local dry cleaner who led the association, reported on the situation, and 10 inhabitants, including local traders and housewives, complained about the hazards caused by the youths. The meeting acknowledged that effective control was impossible under the existing legislation. Those present unanimously signed a plea to be submitted to the metropolitan governor, which demanded tighter control through new legislative measures. ${ }^{43}$

Similar attempts were made in other districts. In Wakaba, Shinjuku Ward, 48 local inhabitants, suffering from late-night noise originating from five hangouts in the middle of a housing district, signed a petition urging the authorities to close them. ${ }^{44}$ In Roppongi, 94 residents signed a similar petition initiated by a housewife who had attended and been inspired by the meeting in Harajuku. ${ }^{45}$ On 10 July 1967, 20 citizens, mainly housewives belonging to the association in Harajuku, and a number from other districts such as Roppongi, visited the metropolitan governor and submitted the petition (Figure 3). ${ }^{46}$

Meanwhile, TMA member Shigeru Kitada submitted written questions to the TMG. Kitada asserted that the Harajuku association meeting had concluded that there was no practical way to eliminate the noise problem without tighter legislative control over such late-night businesses. The young people who patronized the snack bars were typically exuberant, singing, shouting and laughing loudly on and around the premises. The excessive noise was particularly problematic around businesses that had opened in the neighbourhood's quieter areas. Kitada was anxious to know whether the TMG was prepared to establish legislative measures that would enable tighter control of these premises or whether they believed that the existing legislative measures were sufficient to expel the youths and stop the noise. ${ }^{47}$

In response, the TMG underscored the need to pursue control tenaciously, but only through existing legislative measures, which they considered effective. As for new legislative measures, they stated only that they would consider the matter carefully. At the same time, they acknowledged the challenges involved in controlling the noise hazards. In Harajuku's noise survey, the measured background noise levels were in the range of 60-79 phons near the main streets and 43-50 in areas off the main streets. The sound levels of the youths laughing, chanting, chatting and singing outside the premises serving meals and beverages, when measured as a specific sound source, reached 62-7 phons. The TMG regarded this as disturbing the peace in the area, because youths made noise instantaneously and sporadically, which posed practical difficulties in controlling such behaviour. ${ }^{48}$

\footnotetext{
${ }^{42}$ Asahi, 29 Jun. 1967, 15.

${ }^{43}$ Yomiuri, evening edition, 1 Jul. 1967, 9; Asahi, 2 Jul. 1967, 16; and Mainichi, 2 Jul. 1967, 16.

${ }^{44}$ Asahi, 7 Jul. 1967, 16.

${ }^{45}$ Yomiuri, 8 Jul. 1967, 13.

${ }^{46}$ Asahi, 11 Jul. 1967, 16; Mainichi, 11 Jul. 1967, 16; and Yomiuri, 11 Jul. 1967, 13.

${ }^{47}$ Minutes of the TMA Regular Meeting, 20 Jul. 1967, 404-7.

${ }^{48}$ Ibid., 411-13.
} 


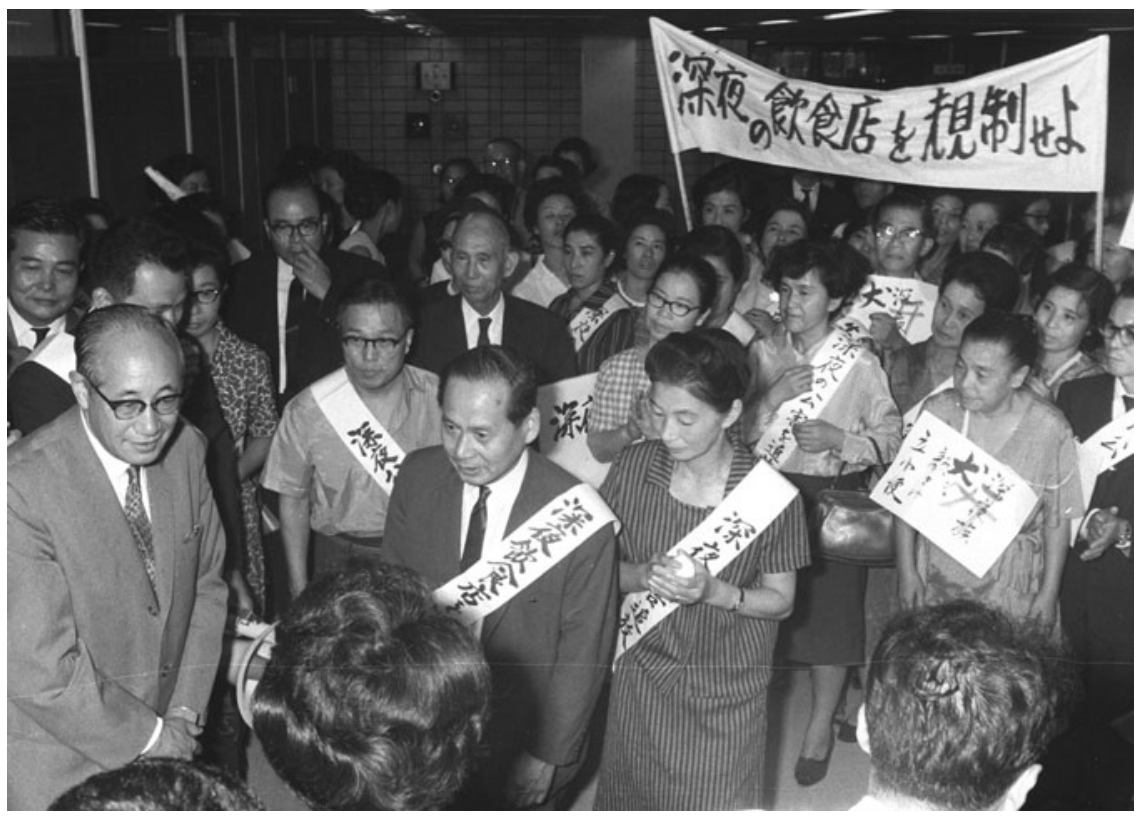

Figure 3. Residents' petition to Governor Minobe (far left, with glasses) in 1967. The banner says 'Regulate the late-night bars and restaurants'. Source: Courtesy of Yomiuri Shimbun.

\section{Establishing legislative measures against noise hazards}

The TMG enacted partial measures against youths like the Harajuku-zoku. On 12 September 1967, the TMG executives' meeting decided to 'totally prohibit' the construction of any premises designated by the metropolitan governor as bars, cabarets, cafés and restaurants in educational districts, which were traditionally part of exclusive residential areas designated under City Planning Law. The TMG's internal memo noted that this was 'a step for the time being'. No limits were placed on establishments that were already constructed and occupied in the educational districts, or new establishments located outside it. This regulation alone would therefore 'not lead to a fundamental solution'. ${ }^{49}$ This decision was reported to the TMA meeting on 28 September $1967 .^{50}$

However, inhabitants in the Harajuku and nearby Sendagaya areas urged the Metropolitan Government to swiftly introduce an ordinance imposing a total ban on businesses operating late into the night, not only in educational districts but also in residential districts as a whole. ${ }^{51}$ They submitted several petitions proposing restrictions on late-night bars and restaurants. These petitions were co-ordinated by local associations not only in the Harajuku/Sendagaya area but

\footnotetext{
${ }^{49}$ Tokyo Metropolitan Archives (TMArchiv.), Tsu405.5.6, 'Harajukuzoku Taisaku nitsuite', 12 Sep. 1967, 1410-12 (quotations 1410 and 1412).

${ }^{50}$ Minutes of the TMA Regular Meeting, 28 Sep. 1967, 63.

${ }^{51}$ Yomiuri, 20 Sep. 1967, 13.
} 
also in Azabu/Roppongi and Shibuya. ${ }^{52}$ Metropolitan Governor Minobe expressed his own discontent that the state legislation was 'extremely insufficient'. ${ }^{33} \mathrm{He}$ also stated that it was 'regrettable [that] the authority granted to the prefectural governor [was] so weak', adding, 'I sincerely hope the forthcoming concerned bills will exert regulatory powers that are as forceful as possible. ${ }^{54}$

Against this background, the House of Representatives' Special Committee on Industrial Pollution Measures - in May 1968 - simultaneously commenced discussions on the Air Pollution Control Bill and the Noise Regulation Bill. Both were intended to provide concrete measures to implement the principles described in the Basic Law for Environmental Pollution Control that was enacted the previous year. The Air Pollution Control Bill was aimed primarily at controlling automobile emissions and smoke from factories. The Noise Regulation Bill was concerned with noise from factories and construction sites, although not with traffic noise, which was dealt with under the Road Vehicles Law and other relevant legislation. The measures aimed at preventing night-time noise emanating from businesses serving meals and beverages were subsidiary: only one out of 33 Articles (Article 28) dealt with this issue. Moreover, that Article merely stated that local authorities had to take measures against night-time noise, including the restriction of opening hours, if it was necessary to protect local citizens' living environment. ${ }^{55}$ However, few questions were raised about late-night noise hazards during discussions of the bill. ${ }^{56}$ In early 1969, following the enactment of the Air Pollution Control Law and the Noise Regulation Law, Minobe continued to express regret that prefectures had to do their best under the still insufficient legislation, which he described as 'administration without authority'. ${ }^{57}$

In May 1969, the TMG proceeded to create a Pollution Prevention Ordinance that was intended as 'a synthesis of the existing metropolitan ordinances regarding smoke control, noise control and industrial pollution prevention with strengthened regulatory standards and extended coverage..$^{58}$ In terms of noise control, the TMG intended to introduce drastic measures to regulate 'late-night noise, which has attracted particular concern as a social issue'. In August 1968, the TMG had conducted an investigation into late-night noise levels 'to obtain basic data...necessary to establish a projected ordinance'. The subject of this investigation were 15 businesses such as snack bars and petrol stations, three each from five districts, namely, Roppongi, Shibuya, Jiyūgaoka, Harajuku and Kōenji. One snack bar in the

\footnotetext{
${ }^{52}$ The petitions were referred to the TMA's Police Affairs and Fire Committee and were adopted by the TMA a year later. Minutes of the TMA Regular Meeting, 4 Oct. 1968, 588 and 610-11.

${ }^{53}$ Minutes of the TMA Regular Meeting, 26 Feb. 1968, 66.

${ }^{54}$ Minutes of the TMA Regular Meeting, 2 Mar. 1968, 305.

${ }^{55}$ Minutes of the House of Representatives Special Committee on Industrial Pollution Measures, 8 May $1968,1-8$ and 21 .

${ }^{56}$ Minutes of the House of Representatives Special Committee on Industrial Pollution Measures, 10 May 1968, 18-19; minutes of the House of Representatives plenary session, 14 May 1968, 1079-83; minutes of the House of Councillors Special Committee on Industrial Pollution Measures, 22 May 1968, 12 and 26-8; and the minutes of the House of Councillors plenary session, 24 May 1968, 801-5.

${ }^{57}$ Minutes of the TMA Regular Meeting, 27 Feb. 1969, 65; and minutes of the TMA Regular Meeting, 5 Mar. 1969, 117.

${ }^{58} \mathrm{~A}$ note to demand the summary of a pollution prevention ordinance bill to be considered by the TMG executives, 14 May 1969, TMArchiv., Tsu406. 6. 4, 'Tōkyōto Kōgaibōshijōreian ni tsuite'.
} 
Roppongi district recorded 24 incidents of noise caused by customer vehicles between 0:00 am and 1:00 am, with 91 decibels (mostly identical to phons) as the highest level. Another snack bar in the Shibuya district recorded 15 occasions of noise caused by customers in the street during the same hour, with 83 decibels as the highest level. ${ }^{59}$

The investigation also noted the numbers of establishments serving meals and beverages after midnight in each of the five districts. There were 316 such establishments: 42 in the Jiyuggaoka district, 27 in the Shibuya district, 96 in the Roppongi district, 137 in the Harajuku district and 14 in the Kōenji district. Save for Kōenji, where all such businesses were located in the designated commercial areas, many of these establishments were located in residential areas: 19 (45.3 per cent of such businesses in the district) in Jiyūgaoka, 24 (89.0 per cent) in Shibuya, 54 (56.3 per cent) in Roppongi and 103 (75.3 per cent) in Harajuku. This totalled 200, accounting for 63.3 per cent of 316 late-night businesses. The report indicated that it would be 'technically impossible' to prevent noise around these businesses, considering that the disturbances were mostly caused by customers or their vehicles outside the premises. Such noise would have a 'profound effect' on local inhabitants because the majority of the premises were located in residential areas. The report concluded by stating that it was 'therefore necessary to consider drastic measures to prevent noise. ${ }^{60}$

In May 1969, the TMG executives' meeting decided to adopt a summary of the Pollution Prevention Bill that would be shown to the political parties on the TMA and then, after becoming a full bill, submitted to the TMA meeting the following month. An internal memo on the TMG executives' meeting summarized Governor Minobe's assertion that the projected bill would be 'quite unique': first, by stipulating that the governor, companies and citizens assumed responsibility for preventing pollution; second, by synthesizing the existing three ordinances that dealt with different types of pollution; and third, by introducing regulations to deal with late-night noise. ${ }^{61}$ Minobe argued that by bringing the various ordinances together, pollution control would be strengthened because the synthesis of administration would overcome sectionalism. ${ }^{62}$

As for the third point, Article 53 of the Draft Bill stated that no person should act or behave in the street or in any other public space in a manner that destroyed, without good reason, the tranquillity in the neighbourhood at night (defined as between 8:00 pm and 6:00 am). Article 54 stated that businesses such as restaurants, teahouses, petrol stations and gambling houses were prohibited from staying open during late-night hours (11:30 pm and 6:00 am). This applied to both residential areas designated under the City Planning Law (unless the TMG decided to exempt a business) and any non-residential areas that the metropolitan governor identified as places where noise might affect tranquillity in an adjacent residential area. The favourable attitude of the TMG toward regulations of late-night noise was reflected

\footnotetext{
${ }^{59}$ TMArchiv., KankyōD219, 'Shinyasōon no Jittai', Oct. 1968, 1-4 and 20 (quotations 1).

${ }^{60}$ Ibid., 134 and 135 (quotation 135).

${ }^{61}$ Memo on the executive meeting on 20 May 1969, TMArchiv., Tsu406. 6. 4, 'Tōkyōto Kōgaibōshijōreian ni tsuite'.

${ }^{62}$ Minutes of the TMA Regular Meeting, 3 Jun. 1969, 82-3.
} 
in Clause 2, Article 54, of a Draft Bill of 21 May 1969, stating that the metropolitan governor could advance the starting time of the late-night hour no earlier than 10:00 pm. However, this clause was eventually deleted. ${ }^{63}$ The TMG executives decided to submit the bill to the TMA on 26 May. ${ }^{64}$

The Pollution Prevention Ordinance Bill was discussed at the TMA meeting on 3 June 1969. The selection of $11: 30 \mathrm{pm}$ as the start time for the ban was a compromise between 11:00 pm, which was advocated by those demanding tighter regulations, and 12:00 am, which had been proposed by those in the food and drink business. ${ }^{65}$ Nevertheless, LDP member Ichiro Takahashi questioned whether 11:30 pm could be regarded as an appropriate time to start the ban, considering that many people finish work late at night. He also criticized the unconditional total ban on businesses as a unilateral measure, given that the source of the noise was not the businesses but the customers who gathered there. A ban on businesses would not necessarily guarantee cessation of the disturbance. Rather, it would be a violation of the freedom of business guaranteed by the Constitution. ${ }^{66}$ Hitoshi Suzuki of the Kōmeitō Party also asserted that many of the establishments subject to the time restrictions were small or micro-business enterprises, whose revenues would be seriously affected. Moreover, a number of them only served meals, and noisy customers were rare on their premises. ${ }^{67}$

Minobe indicated that freedom of business could not be guaranteed unconditionally, but only when such liberty did not conflict with the public welfare. He maintained that a total ban on all types of business was inevitable. Although measures had been taken to crack down on youth partying, these had proven ineffective in controlling noise and preventing sleep disruption to metropolitan citizens. Minobe suggested that the time limits had been determined through a discussion with representatives of the food and drink service industries and the municipalities. The bill was referred to the TMA's General Affairs, Planning and National Capital Improvement Committee (General Affairs Committee). ${ }^{68}$

The Mainichi noted that the political parties in the TMA were mindful of the view in the business community that the restriction on business hours would be harmful to the targeted establishments. ${ }^{69}$ On 7 June 1969, the TMA's General Affairs Committee held a hearing to discuss the issue. Tsuneo Isobe, appointed by the Kōmeito Party as a public speaker, indicated that various businesses did not cause noise hazards and urged 'due consideration' to avoid imposing unfair restrictions on them. Yuji Hosoi, on behalf of the JCP, asserted that any restrictions on business hours should be carefully prescribed and implemented only after a

\footnotetext{
${ }^{63}$ A typewritten draft of Tokyo Pollution Prevention Bill, 21 May 1969, 34-6, TMArchiv., Ku205.17. 3, 'Tōkyōto Kōgaibōshijōrei no Seitei ni tsuite'. Clause 2, Article 54 was crossed out with double lines. See the typewritten draft, 35 .

${ }^{64} \mathrm{~A}$ note on the metropolitan governor's decision on enactment of the Tokyo Pollution Prevention Ordinance, TMArchiv., Ku205.17. 3, 'Tōkyōto Kōgaibōshijōrei no Seitei ni tsuite', decided on 26 May 1969.

${ }^{65}$ Minutes of the TMA's General Affairs, Planning and National Capital Improvement Committee (General Affairs Committee), 7 Jun. 1969, 20.

${ }^{66}$ Minutes of the TMA Regular Meeting, 3 Jun. 1969, 104.

${ }^{67}$ Ibid., 113-14.

${ }^{68}$ Ibid., 110, 120, 148 and 186-7.

${ }^{69}$ Mainichi, 6 Jun. 1969, 16.
} 
careful review of individual cases, regarding not only noise but also circumstances that included persons who were struggling, such as an old man operating a noodle stall at night or a family running a tiny restaurant and barely supporting themselves. $^{70}$

The committee began its discussion of the bill following the hearing. Taro Imaizumi, of the Kōmeitō Party, criticized the unilateral restriction of business hours in Article 54 as 'too harsh and illogical'. He declared himself doubtful about the appropriateness of an ordinance that targeted 'those who do not cause any hazards at all'. He also questioned the designation of zoning under the City Planning Law. This was in effect designated by the TMG, and although there was a revision in 1968, it had originally been designated in 1947. Therefore, there was a question of a case for a residential area when in effect it was a commercial area. ${ }^{71}$ Katsumi Chayama of the JCP also asked for consideration of those businesses that did not cause disturbances. ${ }^{72}$ Against these, Misao Tomizawa, head of the Urban Pollution Section of the National Capital Improvement Bureau of the TMG, maintained that disturbances were primarily caused by customers outside these businesses when arriving or leaving. Since it was not possible to prevent that noise, eradicating the root cause by closing down business activity at night was the only possible solution. Thus, it was inevitable that this would entail 'a total ban of business in the late-night hours in every residential area' designated under City Planning Law. Although there remained the possibility of 'relief measures exempting areas that were residential on paper but had become commercial in practice, such exemptions would be 'indeed exceptional. ${ }^{73}$

Nevertheless, the committee members strove to include this exemption and other allowances in the interest of small or micro-scale commercial interests and manufacturers. At a meeting on 9 June 1969, the JSP urged the consideration of small businesses. Kan Rikimaru, representing the party, demanded that the authorities 'make the most' of the exemption provision to 'take the situation of small or micro-scale businesses into the utmost consideration'. The Metropolitan Governor Minobe responded that businesses that did not cause noise hazards 'should not share the fate of guilty others'. He singled out businesses that served meals for workers - whose shifts ended in the late-night hours - as concerns that should be allowed to remain in operation. In response to requests made by Imaizumi of the Kōmeitō Party and Chayama of the JCP, Minobe guaranteed that 'extra care should be taken not to impose trouble on businesses that do not cause hazards' and that 'particularly the businesses [that] appease the hunger of those working in the late-night hours, such as street stalls, should be treated carefully'. The committee approved the bill with the multipoint supplementary resolution from the political parties, including a clause stating that the ban on late-night business operations should not be applied to establishments that were not causing public hazards. ${ }^{74}$

\footnotetext{
${ }^{70}$ Minutes of the TMA's General Affairs Committee, 7 Jun. 1969, 13 and 15-16.

${ }^{71}$ Ibid., 47-53 (quotations 47 and 50).

${ }^{72}$ Ibid., 64.

${ }^{73} \mathrm{Ibid}$., $50-1$ and 69 (quotations 69).

${ }^{74}$ Minutes of the TMA's General Affairs Committee, 9 Jun. 1969, 3-6, 13, 16, 18-19, 23-5, 30-1 (quotations $4,5,16,18$ and 25).
} 
At the TMA meeting, the bill with the supplementary resolution was approved without objections. ${ }^{75}$ The Mainichi argued that the supplementary resolution would entail a retreat from the desired measures. The paper suggested that the TMA members, facing the forthcoming assembly elections due in July, were anxious to avoid possible blowback from the electorate, by refraining from either opposing or approving the bill without qualification. ${ }^{76}$ Both the conservative LDP and the leftist JCP had political support from different small trader organizations while the Kōmeitō Party had the backing of followers of the Buddhist sect, Sōka Gakkai. As the date set for the enforcement of the ordinance approached, representatives of the residents' groups - who had organized the movement against the late-night noise hazards - visited the TMG to submit a letter expressing their discontent with this retreat. ${ }^{77}$ A month later, Minobe stated that the enforcement of a ban on late-night businesses should be confined to exclusive residential areas, while other areas would vary on a case-by-case basis, taking cognizance of the principle of freedom of business. ${ }^{78}$

\section{Conclusion}

The late-night noise hazards were perceived as a problem that threatened the tranquillity of urban residents who were considered as victims. The noise that the customers of premises serving them meals and drinks in quiet residential areas made was considered the root cause. Local residents urged the TMG to introduce new legislative measures imposing a total ban on late-night businesses in all residential areas. Initially, the TMG stressed the need for a prudent approach based on the existing measures. However, following the ineffective enactment of the Noise Regulation Law, the TMG conducted the investigation and decided to impose a total ban on late-night businesses in all residential areas. At this point, the TMG valued the interest of residents over other involved parties.

However, the political parties with seats in the TMA, including the left-wing JSP and JCP (both supporters of Minobe), opposed the TMG's principle of a total ban by asserting freedom of business in favour of the interest of small businesses, out of fear of losing their seats within the TMA. This affected TMG leaders, who wished to maintain a stable relationship with the TMA. Minobe retracted his argument that freedom of business could not be guaranteed unconditionally and, to the local residents' chagrin, limited the scope of a total ban to the exclusive residential areas and indicated the cognizance of freedom of business in areas other than them. The emphasis was on the demands of the political parties to defend the interests of small businesses.

Therefore, the regulation was a diluted compromise forced by the political considerations. However, it was temporarily effective. A local association of restaurants and tea shops in Harajuku petitioned the TMA for the removal of the ban on latenight business operations in $1972 .{ }^{79}$ However, it did not provide a fundamental

\footnotetext{
${ }^{75}$ Minutes of the TMA Regular Meeting, 9 Jun. 1969, 261.

${ }^{76}$ Mainichi, 10 Jun. 1969, 19.

${ }^{77}$ Asahi, 30 Jan. 1970, 14.

${ }^{78}$ Minutes of the TMA Regular Meeting, 3 Mar. 1970, 176.

${ }^{79}$ Minutes of the TMA Regular Meeting, 19 Oct. 1972, 516.
} 
solution to the noise problem. Reports of late-night noise hazards continued in the 1970 s, such as those caused by youths congregating around bowling alleys ${ }^{80}$ and by motorcycle gangs racing along the Omotesando ${ }^{81}$ Moreover, the method in enforcing the Pollution Prevention Ordinance worsened the regulatory ineffectiveness of noise control. As a progressive local government, the TMG had not permitted the police to deal with complaints from residents about noise. Instead, a unit stationed overnight at the TMG office building answered phone calls from residents and took appropriate action. This unit had been 'swamped with too many calls to handle and was disbanded imperceptibly'. Thereafter, the regulation of late-night noise hazards remained 'virtually ungoverned'. 82

The TMA's pressure to defend the interests of small businesses was a political factor that hindered the TMG from taking drastic measures at the height of their power as progressive local government. The TMG was subject to the concern about votes held by all political parties on the TMA, including the JSP and JCP, the vanguard supporters of the progressive local government. Consequently, the TMG underserved the demand made by the civic activism, which had once been its priority.

Moreover, the TMG was unable to promote the policy themselves. Late-night noise hazards did not entail a confrontation between citizens as victims and big business or the state as perpetrators, as was common in other environmental issues. Here, citizens had to be classed as victims and perpetrators. The TMG was vulnerable to the argument that it neglected the interest of small businesses in the issue. Consequently, it was unable to solve a problem involving conflicting civic interests where it had to decide perpetrators among citizens. ${ }^{83}$

Overall, when Tokyo's urban residents were underserved by the state urban policy for housing, they were also betrayed by the progressive TMG's measures against late-night noise hazards. It must have been difficult to find anyone capable of responding effectively to their demands as urban-dwellers; therefore it is difficult to suggest that the progressive local government had succeeded in encouraging urban policy benefits.

\footnotetext{
${ }^{80}$ Yomiuri, 25 May 1971, 13, and minutes of the TMA Regular Meeting, 17 Dec. 1971, 651-3 and 660.

${ }^{81}$ Minutes of the TMA Regular Meeting, 9 Dec. 1980, 58.

${ }^{82}$ Minutes of the TMA Regular Meeting, 18 Sep. 1986, 41, discussing the karaoke noise hazards emanating from karaoke bars.

${ }^{83}$ After Minobe's re-election as metropolitan governor in 1971, a conflict among Tokyo's residents, the so-called 'rubbish war', broke out over the construction of a waste disposal plant. Residents in Koto Ward, which had long assumed the role of final disposal site, refused to dispose of waste from Suginami Ward, whose residents had campaigned opposing the construction of a new plant in their ward. The TMG was unable to find a solution to the problem, which was finally made possible by the Tokyo District Court's recommendation of a settlement in 1979 between the TMG and the opposition residents. Tsukada, Tokyoto no Shōzō, 162-5; and Okada, Kakushinjichitai, 123-7.
}

Cite this article: Hasegawa J (2023). Late-night noise hazards and the Tokyo Metropolitan Government's countermeasures in the 1960s. Urban History 50, 152-168. https://doi.org/10.1017/S0963926821000717 